\title{
The Uranium Prospects in Mika Region, Northeastern Nigeria
}

\author{
Hinyuen Tsang1, Shamim Akhtar ${ }^{1,2 *}$, Saif-ur-Rehman'2, Qifan Wu ${ }^{3}$, Insung Lee ${ }^{4}$, Nosheen Sahir ${ }^{5}$, \\ Xiaoyong Yang 1
}

${ }^{1}$ School of Earth and Space Sciences, University of Science and Technology of China, Hefei, China

${ }^{2}$ Department of Earth Sciences, University of Sargodha, Sargodha, Pakistan

${ }^{3}$ Department of Engineering Physics of Tsinghua University, Beijing

${ }^{4}$ School of Earth and Environmental Sciences, Seoul National University, Seoul, Korea

${ }^{5}$ Department of Earth and environment Sciences, Bahria University, Islamabad, Pakistan

Email: geotsang2012@yahoo.com.hk, *shamim.akhtar@uos.edu.pk, Saif.rehman@uos.edu.pk, insung@snu.ac.kr,

noshi_a2004@yahoo.com,xyyang555@163.com

How to cite this paper: Tsang, H., Akhtar, S., Saif-ur-Rehman, Wu, Q.F., Lee, I., Sahir, N. and Yang, X.Y. (2018) The Uranium Prospects in Mika Region, Northeastern Nigeria. Open Journal of Geology, 8, 1043-1055.

https://doi.org/10.4236/ojg.2018.811063

Received: September 11, 2018

Accepted: October 7, 2018

Published: October 10, 2018

Copyright $\odot 2018$ by authors and Scientific Research Publishing Inc. This work is licensed under the Creative Commons Attribution International License (CC BY 4.0).

http://creativecommons.org/licenses/by/4.0/

\begin{abstract}
Uranium exploration especially in currently non-producing countries like Nigeria possesses high economic prospect. This study investigates a new uranium prospect in Mika, Northeastern Nigeria. The Mika uranium mineralization is located in Mika, Taraba State. Two lodes were identified and additional nine (9) trenches were added. The main lode in the west extends about 10 $\mathrm{m}$, ore vein strikes $348^{\circ}$, inclination $42^{\circ}$ and the strike of the lode $306^{\circ}$ with average uranium content of $18 \%$. The eastern trench is about $8 \times 4 \times 6 \mathrm{~m}$ which exposes a veinlet of pitchblende. From the petrography, one can deduce that the granitic host rock has suffered deformation resulting in crushing of quartz crystals and stretching of plagioclase. The uraninite and chalcedony in the late phase filled up the fractures along the crystal grain boundaries as veinlets. The laboratory gamma ray analysis of the samples showed that the secondary uranium content is $0.1 \%$, while the primary uranium ore grade is $1.5 \%$. Radiometric in situ measurements showed that $\mathrm{Th}$ and $\mathrm{K}$ ranges from $47.3-3654 \mathrm{ppm}$ and $4.26 \%-6.26 \%$ respectively. From the survey, a strong radiometric zone extends $800 \times 35 \mathrm{~m}$ in a NW-SE direction and has highest radiation content of $1200 \mathrm{cpm}$ against the background count rate of $30 \mathrm{cpm}$. Generally, the uranium concentrations in the ores in Mika area range from $0.03 \%-0.12 \%$. Since only the surface occurrences have been explored, the study area is a good prospect for future development when properly explored. The North-eastern Nigeria has been roughly explored by Nigeria Uranium Mining Company (NUMCO) in 1980, but no formal exploration had been followed after that, especially near the site of this article. The company
\end{abstract}


(ACE Mines, Ltd) of the first author was among the few uranium mining companies approved in the list of Nigerian Geological Survey agency of Abuja in Nigeria. The authors determined the coordinates of the site in their first survey which formed the prospect area in the licence.

\section{Keywords}

Uranium Exploration, Uranium Mineralization, Radiometric Zone Mika Area, Nigeria

\section{Introduction}

Uranium has become a prominent energy resource in many countries as the principal fuel for nuclear power plants [1]. It has been projected that the cumulative aggregate world uranium requirements far outweigh production capacity from the existing and planned centers. To balance such demand on a worldwide basis; enormous additional mining centers are needed. In the long term, new occurrences must be prospected and explored for production. This forecast should lead to a renewed interest in uranium exploration especially in currently non-producing countries like Nigeria with high future energy demand.

Uranium occurrences in Nigeria are found in sedimentary sequences and deformed granitic basement rocks. Although most of these occurrences are small and scattered, the major occurrences are the Ghumchi, Kanawa and Mika prospects in granitic rocks; and the Zona and Dali occurrences in the Bima Sandstone. These prospects are restricted to northeastern Nigeria and were all discovered by Nigeria Uranium Mining Company (NUMCO). Prior to their discovery, efforts in uranium exploration in Nigeria were concentrated towards the Younger Granite Province in the North Central Nigeria. These include the Riruwai ring complex and Kigom hills where pyrochlore disseminations were reported but where no significant prospect was discovered [2].

This article is a summary of several investigations conducted by the survey teams organized by "AlanCrawley Enterprises, Ltd" which later on formed a local subsidiary company (ACE Mines, Ltd) and owned the exploration rights of the target site in the Mika area.

\section{Regional Geology}

The oldest rocks in the region comprise migmatites and pre- to synkinematicgranitoids (Table 1) with emplacement ages ranging from 680 to $620 \mathrm{Ma}$. This basement was intruded by orogenic granites [3], post kinematic granitoids with emplacement ages ranging from 620 to $590 \mathrm{Ma}$.

Mesozoic magmatism has been described by [4] giving ages of $147 \pm 7 \mathrm{Ma}$ and $103 \pm 5$ Ma respectively. The initial magmatic activity was bimodal in nature, consisting of alkaline rhyolites (Burashika) and transitional alkaline basalts (Shani). The second involved transitional alkaline basalts and tholeiitic basalts. 
Table 1. Summary of the regional geology of NE Nigeria.

\begin{tabular}{|c|c|c|}
\hline Pleistocene & & Deposition of Chad Formation \\
\hline $\begin{array}{l}\text { Late Tertiary } \\
\text { to Quartenary }\end{array}$ & & Basalt (Biu and Longuda Plateux), trachyte and phonolite \\
\hline Paleocene & & Uncomformable deposition of Keri Keri Formation \\
\hline \multirow{4}{*}{ Cretaceous } & Maastrichtian & Deposition of Dukul, Pindiga, Jessu \\
\hline & $\begin{array}{l}\text { Lower Turonian } \\
\text { to Campanian }\end{array}$ & Gongila Formation (marine beds of clays, shales limestone) \\
\hline & Cenomanian & Yolde Formation ( with calcareous units) \\
\hline & Albian & Bima Sandstone deposition \\
\hline Mesozoic & $\begin{array}{c}147 \pm 7 \mathrm{Ma} \\
(103 \pm 5 \mathrm{Ma})\end{array}$ & $\begin{array}{l}\text { Alkaline rhyolites (Burashika) } \\
\text { and transitional alkaline basalts (Shani) }\end{array}$ \\
\hline \multirow{3}{*}{ Precambrian } & $620-590 \mathrm{Ma}$ & $\begin{array}{l}\text { Post-kinematic emplacement of granitoids } \\
\text { (biotite, biotite-muscovite granites and pegmatites) }\end{array}$ \\
\hline & $680-620 \mathrm{Ma}$ & Migmatite and ante to synkinematicgranitoids (granite gneiss) \\
\hline & & Deposition of sedimentary succession \\
\hline
\end{tabular}

The host rock of the region is part of the Pan-African basement complex and consists mainly of medium grained granite which is, in places, intruded by rhyolites and siliceous veins. Regional Geology of NE Nigeria is also summarized in Table 1.

There is no record of sedimentation in the long interval between Precambrian and late Mesozoic times. The oldest sedimentary rocks are thick and widespread series of continental grits, sandstones and clays of the Bima Sandstone. The Bima Sandstone is subdivided into three main siliciclastic members, the lower, middle and upper members [3]. Transgression of the sea in Middle Cenomanian led to deposition of the Yolde Formation [5]. A widespread, shallow marine transgression occurred during Lower Turonian times, as evidenced by marine beds of clays, shales and limestones of the Dukul, Pindiga, Jessu and Gongila Formations. Marine conditions persisted until the Maastrichtian and were accompanied in the south by localized volcanic activity [3] [5]. Over the northern and central areas marine conditions gave way to deltaic and estuarine environments in which the Gombe Sandstone was deposited. This was followed by a period of folding which resulted in the development of major anticlinal structures affecting the whole sedimentary succession [5]. A younger sequence of continental deposits, the Keri-Keri Formation was laid down in the Paleocene [3] [5]. The continental sedimentation was followed by a period of extensive laterite formation overlying the Keri Keri Formation. During the late Tertiary and Quaternary, widespread volcanic activity occurred in the southern and central areas giving rise to Biu and Longuda Plateaux and small volcanic plugs were intruded over the area in the age range from $7 \mathrm{Ma}$ to $1 \mathrm{Ma}$ [4].

The regional structural patterns are dominated by a series of large NE-SW trending faults and folds, parallel to the Benue Trough. Folding and strike slip 
faulting results from a horizontal regional compression acting in a $\mathrm{N} 160^{\circ} \mathrm{E}$ mean direction which is related to Late Cretaceous compressive tectonic phase by [6] [7]. The basement rocks display many joints, fractures and faults. The most dominants are the faulted boundary between the Basement and the Early Cretaceous sedimentary basins which follow $\mathrm{N} 110^{\circ}-\mathrm{N} 120^{\circ}$ (Chad) trend and $\mathrm{N} 60^{\circ}$ $\mathrm{N} 70^{\circ}$ (Benue) trend [8]. There is the NS dominant structural trend of both foliation and joint directions and its extensional EW direction. The NS trend in some places extends in to the sedimentary rocks. An EW extensional phase of Tertiary age may be related to the development of the volcanic centers of Biu and Longuda and The Cameroun volcanic line (CVL) [4] [9].

\section{The Geology of the Mika Area}

The outcrops of Mika area are dominated by granites including fine-grained granite, medium-grained granite and porphyritic granite (Figure 1). There are two major types of ores in the Mika uranium mineralizations, the primary mineralization at depth occurs as pitchblende, whereas supergene secondary mineralizations are mainly meta-autunite and coffinite occurring near the surface [11].

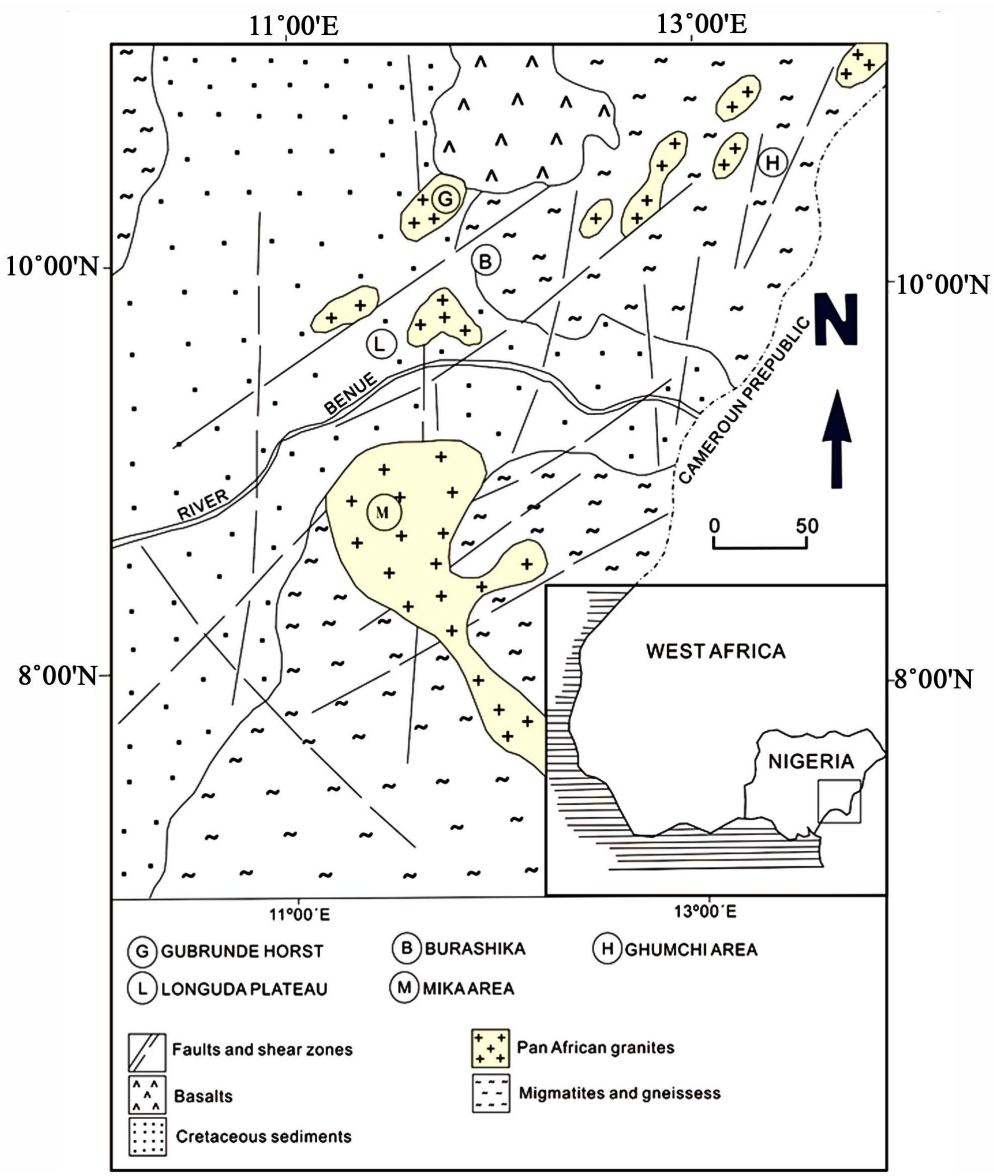

Figure 1. Geological map of part of northeastern Nigeria showing localities of uranium mineralization [10]. 
The mineralization is structurally controlled. The first is associated with normal faults in N160E to N170E gash faults converging onto a major N130E wrench zone; here firstly, $U$ is disseminated within the brecciated hematized granites in millimetricve inlets crosscutting the granitic clasts.

The second is concentrated within a N160E vertical open gash fault which is inherited from the extensional fault [12], network filled by clastic deposits in a vertical plane exhibit sedimentary microstructures similar to graded bedding. Secondary uraniferous minerals originated by surface leaching of pitchblende which occurs within the surrounding hematized granites

\section{Field and Petrographic Studies}

Two lodes were partially mined by open pits covering an area of about $200 \mathrm{~m}^{2}$ [13]. The two lodes trend in N-S direction about $2 \mathrm{~km}$ with a thickness of about $150 \mathrm{~m}$ in the $\mathrm{E}-\mathrm{W}$ direction and depth of about $30 \mathrm{~m}$. The two lodes are located in the sheared granites hosted by porphyritic granites which are highly sheared and jointed in the N-S direction.

\subsection{Uranium Prospects}

There is a mining pit on each of the two lodes, they are located in the south side of the hill about $60 \mathrm{~m}$ from the summit. The main western pit extends about $10 \mathrm{~m}$. An ore vein strikes at $348^{\circ}$, inclination angle $42^{\circ}$, strike of mineralized zone $306^{\circ}$. The silicic vein is narrow (Figure 2 ). The concentration of uranium ranges from $18 \%$ in average, the highest concentration is $30 \%$. Unfortunately, the pit is flooded so a sample of the pitchblende could not be obtained. The eastern pit extends about8m on strike, is $4 \mathrm{~m}$ wide and $6 \mathrm{~m}$ deep. The veinlet of pitchblende is visible and is about $10 \mathrm{~cm}$ wide.

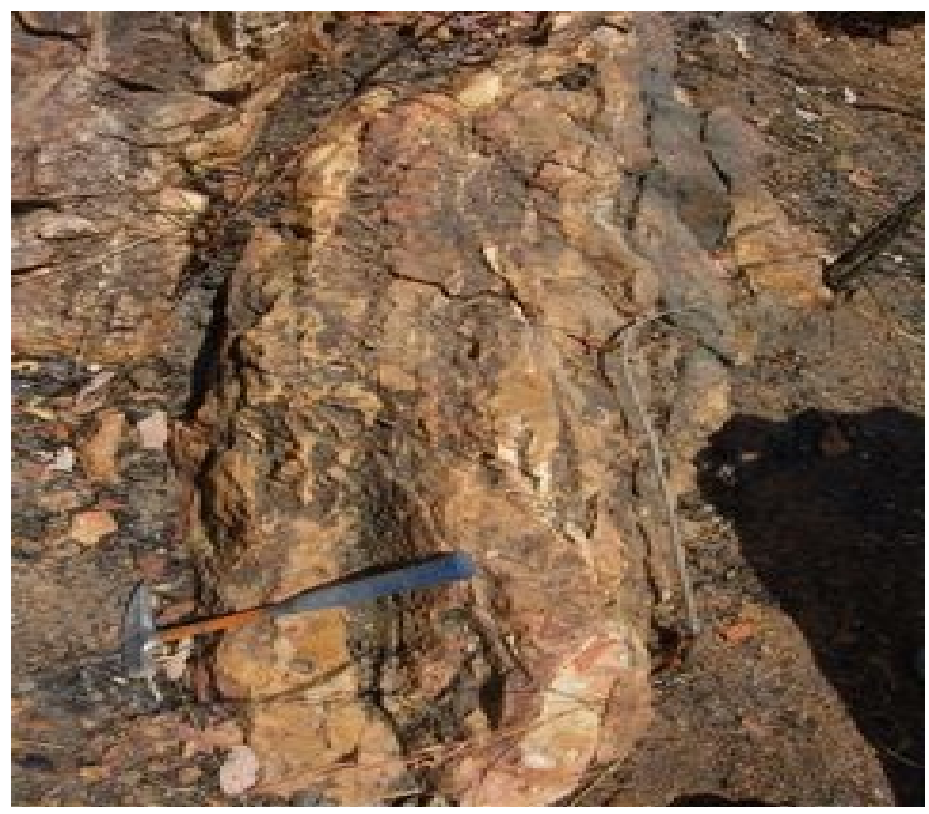

Figure 2. Silicified radioactive vein at Mika. 
The surrounding rocks have high radiation anomaly spots and a distribution of small uranium veins hosted in Pan-African Porphyritic granites, the U-Pb dating of the refractory minerals revealed an age of $579 \pm 3 \mathrm{Ma}$ [15]. Around the lode, secondary uranium ores are abundant, scattered all over. These secondary uranium ores have not been studied, but may consist of either uranophane or rameauite. The lode is highly silicified near its contacts with granite host rock, and the granitic host rock adjacent to the mineralized portion of the lode is also pervasively altered, its feldspars altered to kaolinite. On the mineralized portion, alteration is highest at the peak and tends to be less intense away from the center. In Mika area, uranium occurs in the Pan-African granites with $10.0 \mathrm{ppm}$ uranium while in Gumchi area, the assessed uranium content is $114 \mathrm{ppm}$ in Jurassic rhyolite dykes [14]. A radiometric map is prepared for the prospected region (Figure 3).

The above map was prepared by using Gamma Scout Radiation Counters which measure alpha, beta and gamma either separately or combined. In all, over 3250 radiation counts and more than 3250 elevation data were collected. Areas of possible uranium mineralization are seen as areas in deep red color. Trends of major radiometric anomaly shown on the map are generally NW-SE, truncated by a minor NE-SW trend.

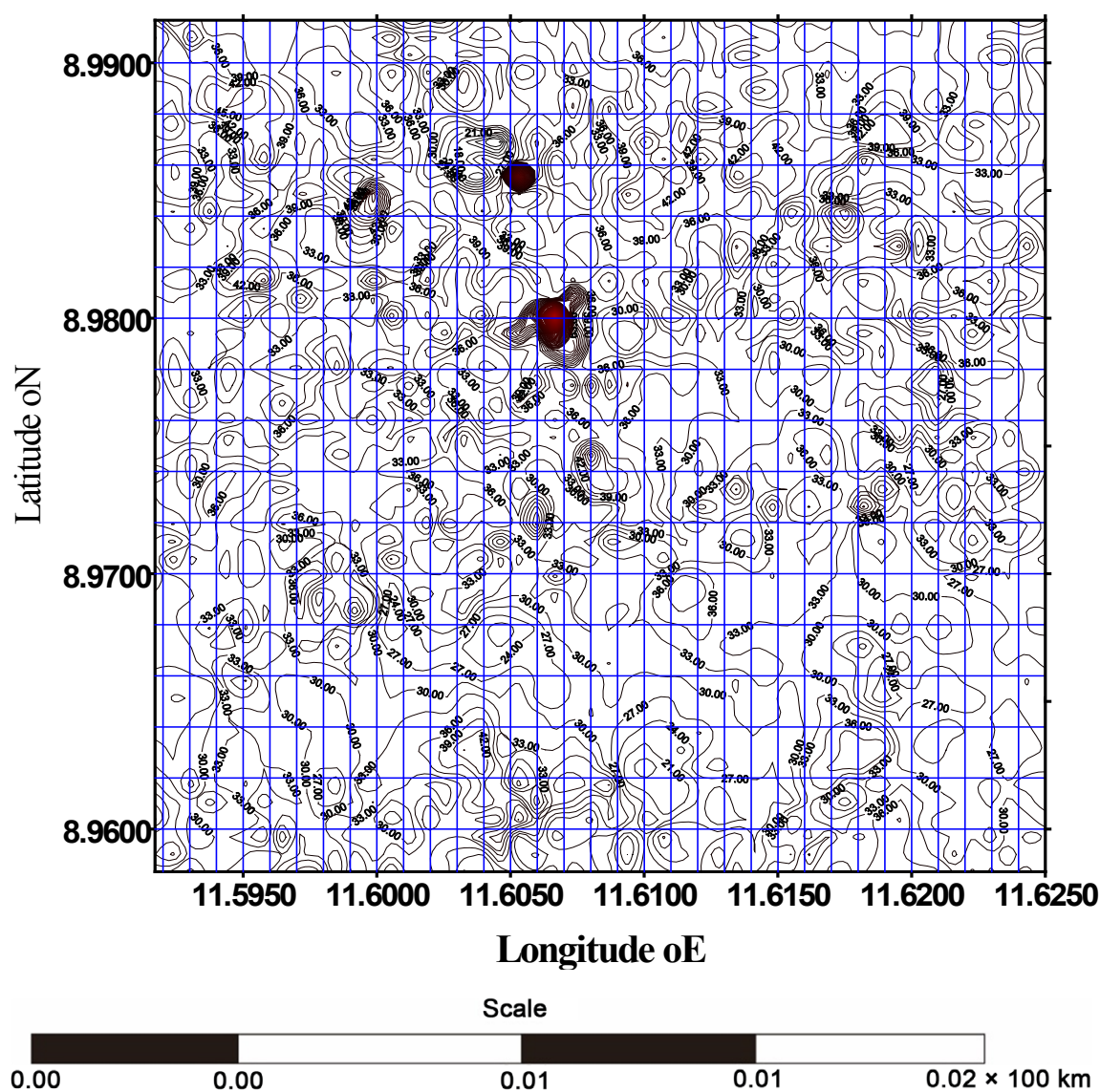

Figure 3. The Radiometric Map of Mika area, Taraba State, Nigeria (prepared by Dr. A.O. Solomon of ACE Mines, Ltd). 


\subsection{Petrography}

Thin sections were prepared from samples obtained from both sides of the lodes and include samples of the silicified zone, highly altered granite and weakly altered granite.

Silicified zone: Mainly made up of broken quartz and feldspar about 30\% $35 \%$ with siliceous cement, crystal diameters ranges from $0.01-3.5 \mathrm{~mm}$, with a lot of ferrous opaque minerals mainly hematite, the sheared fragments contains $80 \%$ quartz, 20\% feldspar. Quartz and feldspar granules portray a deformational signature in a specific direction, wavy extinction phenomena on the granules of quartz is an evidence of deformation. The quartz and feldspar granules are broken due to shearing. Poly crystalline quartz grains, albite plagioclase grains, microcline, tourmaline and epidot and zircon inclusions in quartz grains observed (Figure 4).

Highly altered granite: The mineralogy is a typical of granite, mainly quartz, microcline, orthoclase and few plagioclase and biotite flakes. The feldspars are highly altered. Quartz and feldspar granules are broken as result of shearing and chalcedony veinlet. The chalcedony vein is directional and quartz with obvious wavy extinction. There are some granules with glomeroporphyritic texture which contain magnetite with diameter $0.2-0.3 \mathrm{~mm}$.

Weakly altered granite: This contains a lot of microcline as well as small plagioclase granules are enclosed called perthite. The granules are cracked and string of chalcedony agglomerates are found in the cracks with crystal sizes from
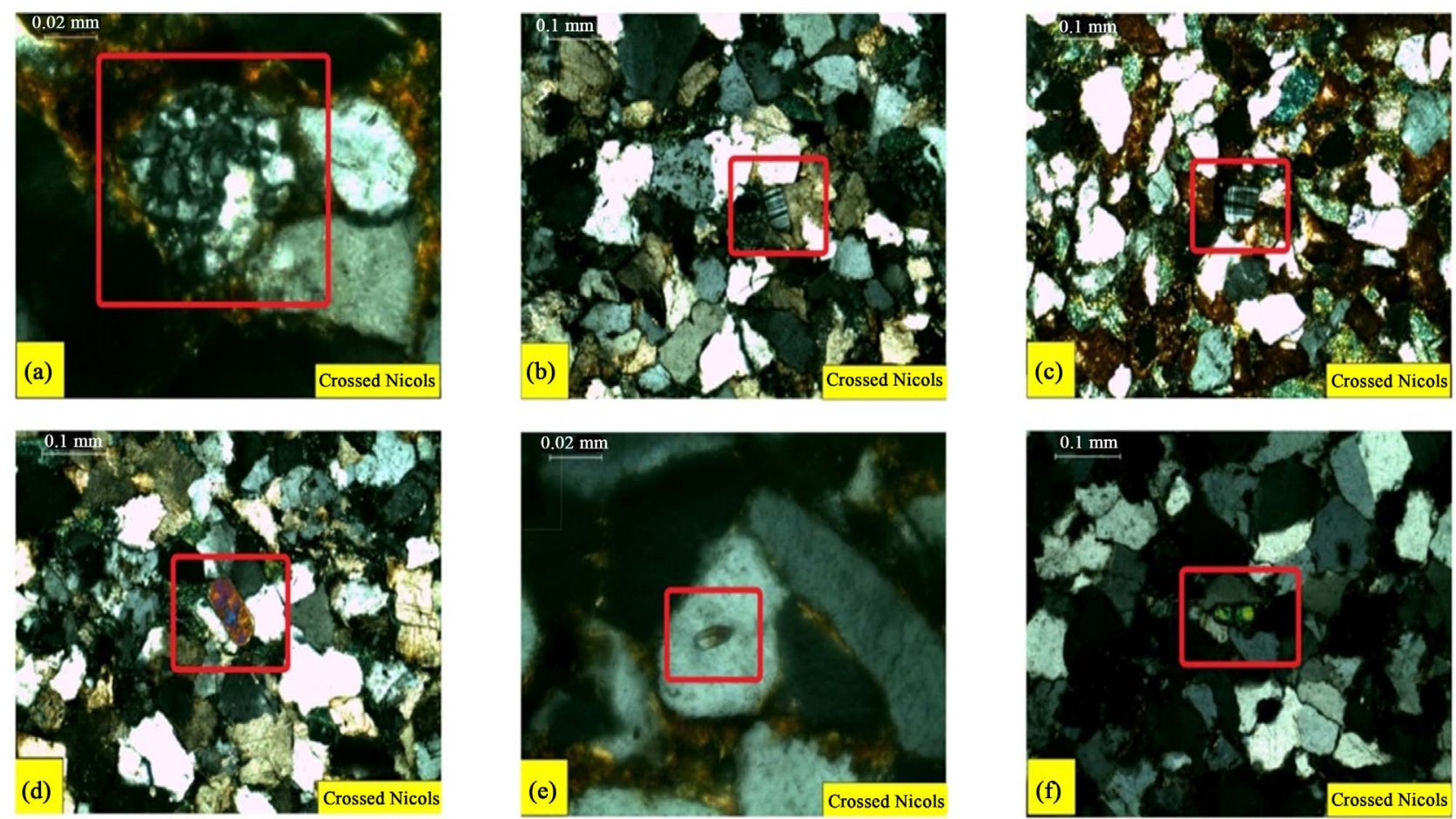

Figure 4. Photomicrograph showing, (a) poly-crystalline quartz grain; (b) albite plagioclase grain; (c) microcline grain; (d) tourmaline grain; (e) zircon inclusion in quartz grain; (f) epidote grain. 
$0.1-0.3 \mathrm{~mm}$. Moreover, feldspars are deformed quartz crystals are crushed and there is evidence of shearing in the structure of mosaicchalcedony.

From the petrographic studies one can deduce that the host rock has suffered deformation resulting in the crushing of the quartz crystals by brittle deformation and the lensoidal nature of the plagioclase ductile deformation by shearing. The uraninite and chalcedony in the late phase filled up the fractures along the crystal grain boundaries in form of veinlets.

\section{Radiometric and Gamma Dose Measurement}

We located two lodes in the direction of NNW in our first survey in November, 2006.

The first survey route was conducted in NE direction using gamma spectrometer to measure the radiation along the path towards the western portion of lode extends about $160 \mathrm{~m}$ (Figure 5 and Figure 6). All the instruments and spectrometers for the survey were calibrated.

The second survey route is along the west-east direction across the two lodes (Figure 7) and is $150 \mathrm{~m}$ long. Due to the reason of short survey routes, gamma dosimeter and gamma spectrometer were used, the measuring points are within the anomalous region (relative to the background radiation). The measurement of the two lines along northeast and north-south direction showed the ground exposed lode is distributed several tenth of meters on the western side, and is already over minimum requirement of Chinese industrial grade for exploitation (uranium content is $30 \mathrm{ppm}$ ), maximum ground measurement value is 1200 ppm.

The result of survey in east-west route also showed that the grade of the upper portion of the two lodes is also over the minimum requirement for the industry

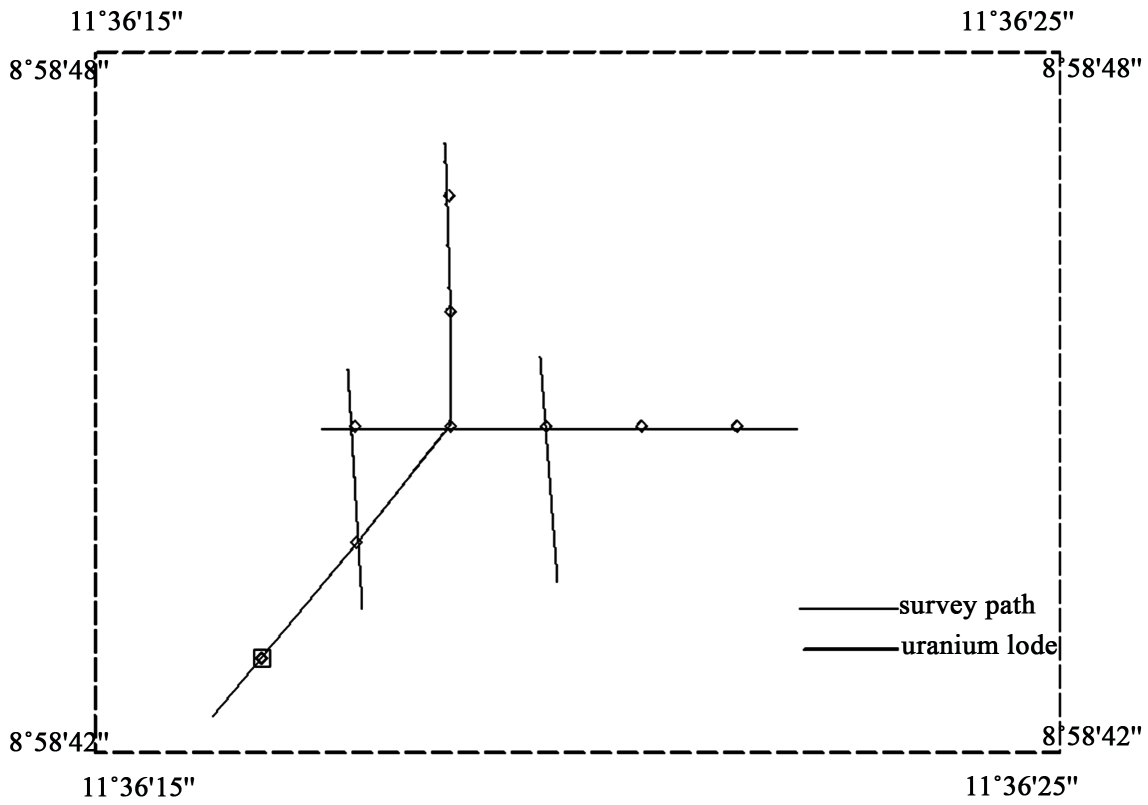

Figure 5. The profile for radioactive survey around uranium lodes. 

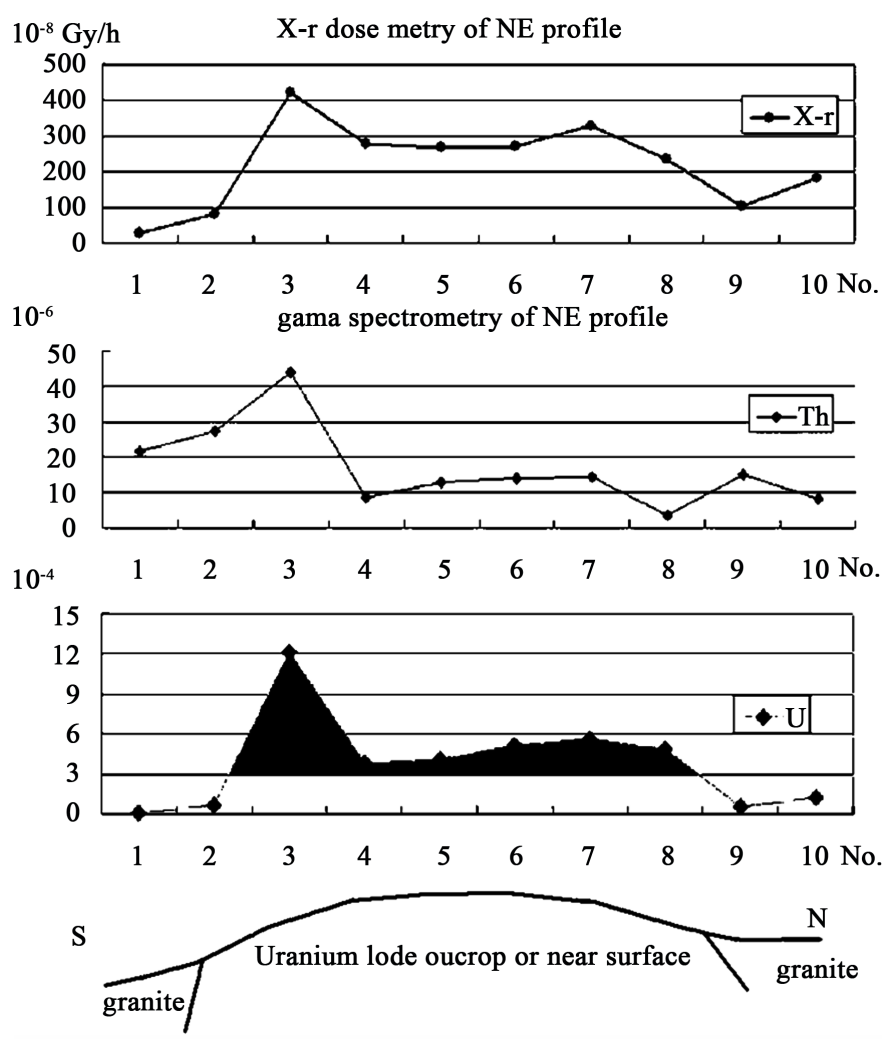

Figure 6. SE-N profiles for radioactive survey.
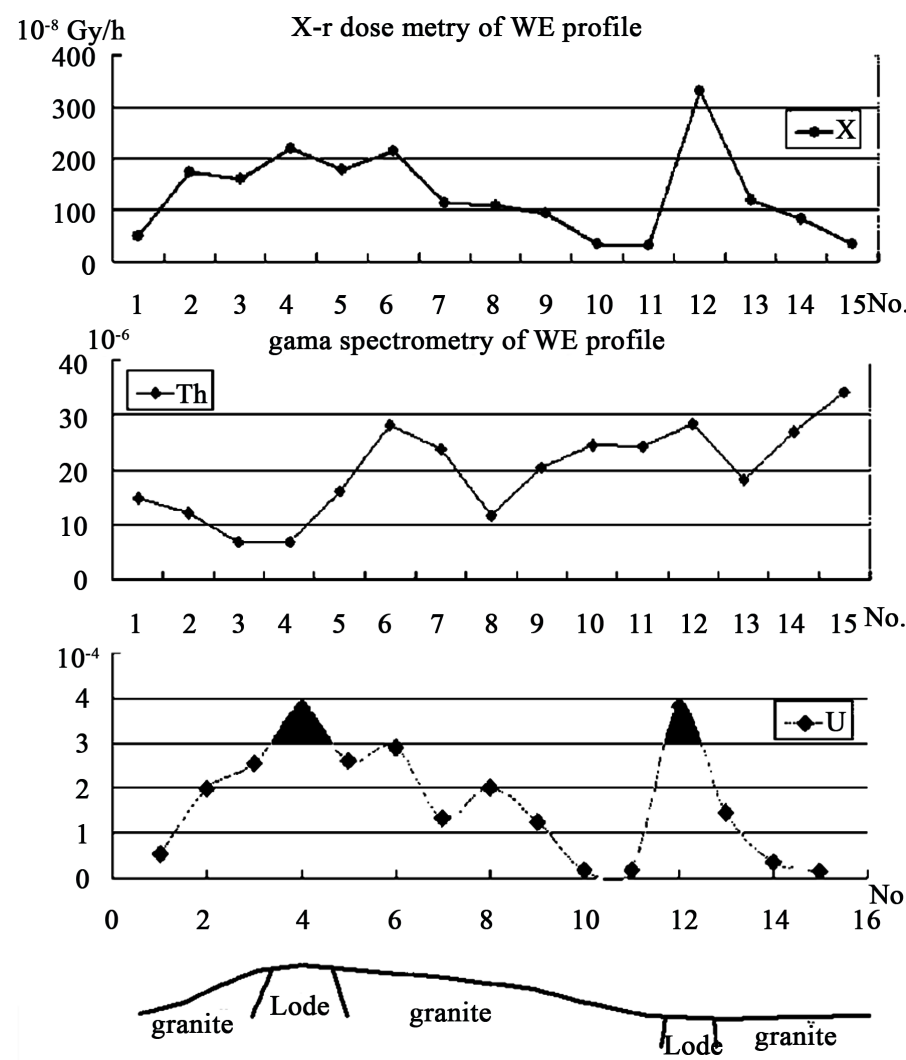

Figure 7. W-E profiles for radioactive survey. 
exploitation; the value is about $400 \mathrm{ppm}$. The west lode in the ground could be wider from observation; it might be possible that the lodes are not connected. The laboratory gamma ray analysis of the samples from the site shows the content of secondary uranium ore is approximately $0.1 \%$, while the primary uranium ore is $1.5 \%$. Radiometric in situ measurements showed thorium and potassium rages from 47.3 - $265.4 \mathrm{ppm}$ and $4.26 \%$ - 6.26\% respectively (Table 2). On site measurement of rock samples also showed that thorium and potassium are within normal level for granite, they are $28.3-36.7 \mathrm{ppm}$ and $2.3 \%-2.8 \%$ respectively.

From the mapping, a strong radiometric zone approximately $800 \mathrm{~m}$ in length with width varying between 20 to $50 \mathrm{~m}$ is defined. This zone trends in the NW-SE direction as shown in Figure 8. Peak surface count rates here are in excess of $1200 \mathrm{cpm}$ as against a general average background of about $30 \mathrm{cpm}$.

Nine (9) new exploration trenches were dug (Figure 9 and Figure 10). Six (6) to the NNW along strike of the original workings for a distance of 707 meters, and a trench to the SSE along strike some 250 meters from the main workings for a total strike length of 957 meters. Two exploration trenches, 9 and 7, off the Base Line were dug; one to the ENE and one to the WNW of the Zero Station. Trench lengths varied from 10 to 70 meters each.

Table 2. Measurements from collected rock samples (From team of Dr. A.O. Solomon).

\begin{tabular}{|c|c|c|c|c|c|c|}
\hline Sr. No & Sample No & $\mathrm{K} \%$ & $\begin{array}{c}\mathrm{U} \\
(\mathrm{ppm})\end{array}$ & $\begin{array}{c}\mathrm{Th} \\
(\mathrm{ppm})\end{array}$ & $\begin{array}{c}\text { Total } \\
\text { Counts/Sec }\end{array}$ & $\begin{array}{c}\text { Dose Rate } \\
(\mathrm{Gy} / \mathrm{h})\end{array}$ \\
\hline 1 & MIKA1 & 2.64 & 8.5 & 30.2 & 462.3 & 158.2 \\
\hline 2 & MIKA2 & 2.88 & 18.3 & 31.3 & 486.5 & 220.2 \\
\hline 3 & MIKA3 & 3.17 & 10.2 & 35.1 & 472.3 & 187.2 \\
\hline 4 & MIKA4 & 2.81 & 10.8 & 29.9 & 466.7 & 173.1 \\
\hline 5 & MIKA5 & 2.7 & 15.8 & 36.7 & 485.1 & 217.1 \\
\hline 6 & MIKA6 & 2.7 & 9.7 & 32 & 468.2 & 170.7 \\
\hline 7 & MIKA7 & 2.8 & 12.5 & 26.5 & 472.3 & 174.1 \\
\hline 8 & MIKA8 & 2.55 & 19.5 & 35.7 & 482.9 & 233.7 \\
\hline 9 & MIKA9 & 3.25 & 11.4 & 28.8 & 471.2 & 179.1 \\
\hline 10 & MIKA10 & 2.72 & 17.9 & 28.5 & 475.8 & 208.9 \\
\hline 11 & MIKA11 & 2.88 & 9.5 & 29.2 & 467.5 & 164.7 \\
\hline 12 & MIKA12 & 2.75 & 18.6 & 25.3 & 479.3 & 205.4 \\
\hline 13 & MIKA13 & 2.3 & 17.6 & 31.8 & 476.6 & 209.4 \\
\hline 14 & MIKA14 & 2.65 & 19.9 & 27.2 & 483 & 215.7 \\
\hline 15 & MIKA15 & 2.6 & 27.2 & 32.6 & 499.9 & 269.9 \\
\hline 16 & MIKA16 & 2.76 & 25.6 & 28.3 & 493 & 252.1 \\
\hline
\end{tabular}




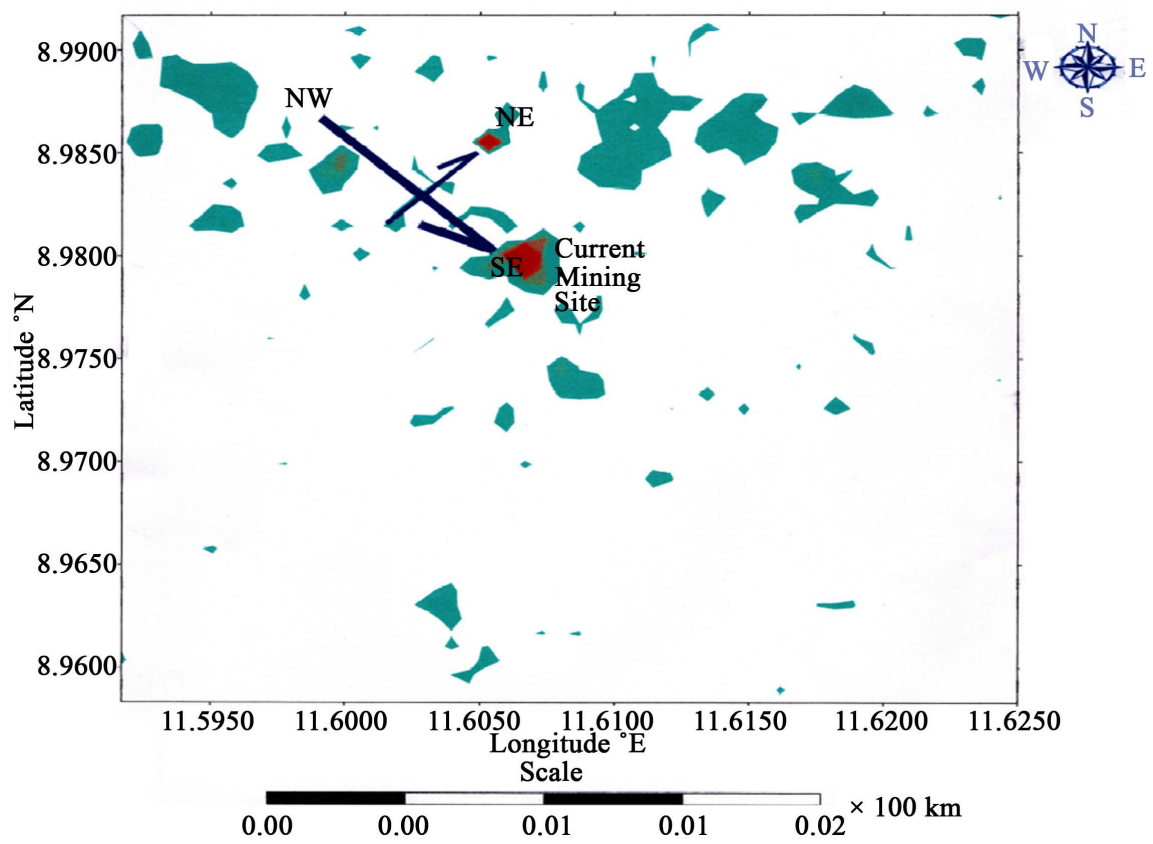

Figure 8. Major Radiostructural trends in the Mika area, Taraba State, Nigeria [13].
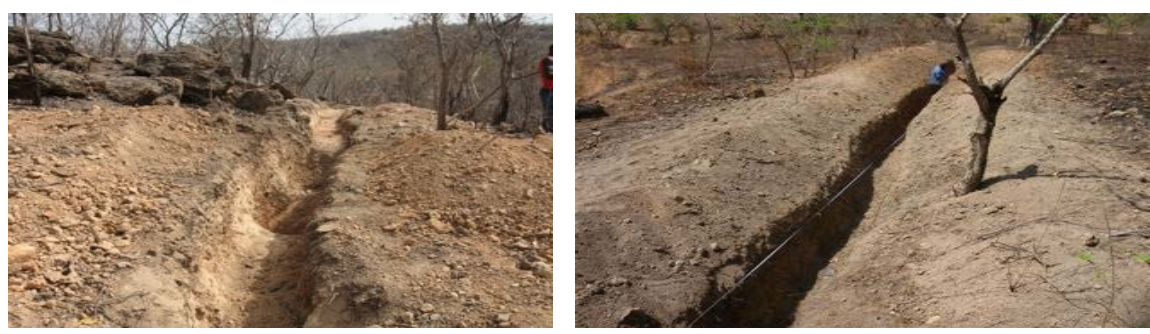

Figure 9. The new trenches No. 3 and No. 4 dug during the prospecting.

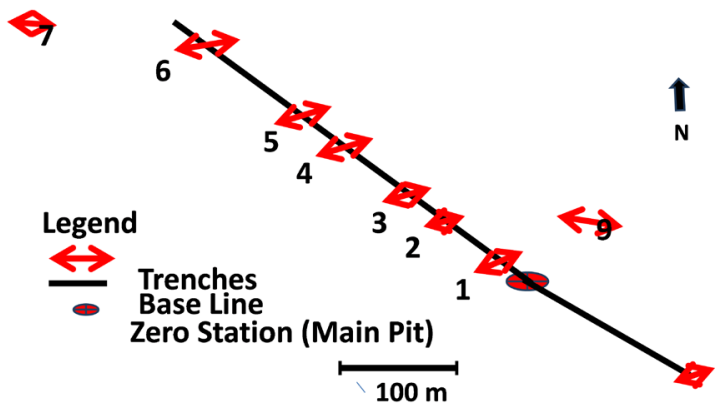

Figure 10. Direction of the trenches [14].

\section{Conclusion}

From the petrography the granitic host rock showed pervasive alteration, the lode itself is zoned, at the edges is the weakly altered to highly altered granite mainly made up of microcline and a mosaic of chalcedony, whereas the mineralized silicified zone at the peak of the lodes showed presence of mainly opaques minerals. The evidence from the microscopic studies showed that the rock has suffered deformation in different degrees resulting in the crushing of quartz and 
lensoidal nature of the plagioclase mainly by shearing. The primary uranium minerals observed are uraninite and pitchblende while the secondary uranium ores could be either uranophane or rameauite which are all associated with chalcedony and ferrous minerals.

The uranium mineralization occurred mostly within the brecciated zone, structurally controlled along N-S trend but the depth of mineralization is yet to be investigated, uranium mineralization is more intense at the contact between the silicified zone and the host rock. The radiometric readings of $\mathrm{U}$ and Th concentrations are higher in areas with higher dose rate $(\mathrm{Gy} / \mathrm{h})$.

The ACE mines organized several teams for the investigations, new lodes have been found and the dense radiation areas were identified, measurements were made in-situ as well as on samples collected from different location. However, the surveys mainly restricted on the shallow surface because the instruments can not disclose any depth extent of mineralization though many trenches were dug in the project.

The uranium concentration in the ores is about $0.03 \%-0.12 \%$, peak surface count rates here are in excess of $1200 \mathrm{cpm}$ as against a general average background value of about $30 \mathrm{cpm}$. The Mika uranium mineralization site is a good prospect target for future exploration.

\section{Acknowledgements}

This work is supported by National Program on Key Basic Research Project (973 Program) (2015CB453002). We thank Mr. Alan Crawley, the President of Alan Crawley Enterprises, Ltd and ACE Mines, Ltd (Nigeria) for allowing us to disclose the data of the investigations conducted by his company.

\section{Conflicts of Interest}

The authors declare no conflicts of interest regarding the publication of this paper.

\section{References}

[1] International Atomic Energy Agency (IAEA) (2009) World Distribution of Uranium (UDEPO) with Uranium Deposit Classification. IAEA-TECDOC-1629.

[2] Dada, S.S. and Suh, C.E. (2006) Finding Economic Uranium Deposits and the Nigerian Energy Mix. First PTDF Workshop Proceedings, University of Maiduguri, Maiduguri, 34-43.

[3] Carter, J.D., Barber, W. and Tait, E.A. (1963) The Geology of Parts of Adamawa, Bauchi and Borno Provinces in the Northeastern Nigeria. Geological Survey of Nigeria Bulletin, 30, 106.

[4] Coloun, C., Vidal, P., Dupuy, C., Baudin, P., Popoff, M., Maluski, H. and Hermitte, D. (1996) The Mesozoic to Early Cenozoic Magmatism of the Benue Trough (Nigeria); Geochemical Evidence for the Involvement of the St. Helena Plume. Journal of Petrology, 37, 1341-1358. https://doi.org/10.1093/petrology/37.6.1341

[5] Abubakar, M.B. (2006) Biostratigraphy, Paleoenvironment and Organic Geochemistry of the Cretaceous Sequences of the Gongola Basin, Upper Benue Trough, Nigeria. Unpublished PhD Thesis, Abubakar Tafawa Balewa University, Bauchi, 289 p. 
[6] Benkhelil, J. (1982) Benue Trough and Benue Chain. Geology Magazine, 119, 115-168. https://doi.org/10.1017/S001675680002584X

[7] Benkhelil, J. (1986) Structure et Evolution Geodynamique du Basin Intercontinental de la Benoue (Nigeria). These de Doctoratd'Etat, Universite de Nice, 226.

[8] Guirand, M. (1990) Tectono-Sedimentary Framework of the Early Cretaceous Continental Bima Formation (Upper Benue Trough, Northeastern Nigeria). Journal of African Earth Sciences (and the Middle East), 10, 341-353. https://doi.org/10.1016/0899-5362(90)90065-M

[9] Rankenburg, K., Lassiter, J.C. and Brey, G. (2004) Origin of Megacryst in Volcanic Rocks of the Cameroon Volcanic Chain-Constraints on Magma Genesis and Crustal Contamination. Contributions to Mineralogy and Petrology, 147, 129-144. https://doi.org/10.1007/s00410-003-0534-2

[10] Maurin, J.C. and Lancelot, J.R. (1990) Structural Setting and U-Pb Dating of Uranium Mineralizations from the NE, Nigeria (Upper Benue Trough). Journal of African Earth Science, 10, 421-433. https://doi.org/10.1016/0899-5362(90)90095-V

[11] Funtua, I.I., Okujeni, C.D. and Elegba, S.B. (1999) Preliminary Note on the Geology and Genetic Model of Uranium Mineralization in Northeastern Nigeria. Journal of Mining and Geology, 35, 125-136.

[12] Wu, Q.-F. and Tsang, H.-Y. (2006) The Geological Survey Report of Uranium, Ta-Nb Mines in Nigeria. Pacific Ores Metals and Chemicals, Ltd., Hong Kong, 46 p.

[13] Free, G.M. (2010) The Mika Uranium Project. Alan Crawley Enterprises, Ltd.

[14] Obaje, S.O., Ojutalayo, A., Ogedengbe, O. and Okosun, E.A. (2014) Nigeria's Phosphate and Uranium Mineral Occurrences: Implications for Mineral Investment. Journal of Environment and Earth Science, 4, 83-89.

[15] Mosoh Bambi, C.K., Frimmel, H.E., Zeh, A. and Su, C.E. (2013) Age and Origin of Pan-African Granites and Associated U-Mo Mineralization at Ekomédion, Southwestern Cameroon. Journal of African Earth Sciences, 88, 15-37. https://doi.org/10.1016/j.jafrearsci.2013.08.005 